\title{
A Bibliometric Analysis of Death Education Research: 1970-2021
}

\author{
Zeynep Funda Sonbul
}

Department of Educational Sciences, Graduate School of Education, Ankara University, Ankara, Turkey

Corresponding Author: Zeynep Funda Sonbul, zfundasonbul@gmail.com

Article Type: Research Article

Acknowledgement: I would like to thank my mentor Assoc. Prof. Dr. Raşit Çelik who contributed the development of this article with his valuable comments.

To Cite This Article: Sonbul, Z. F. (2021). A bibliometric analysis of Death Education Research: 1970-2021. Ë̆itimde Kuram ve Uygulama, 17(1), 98-113. doi: 10.17244/eku.916222

Ethical Note: Research and publication ethics were followed. In this study, the data were openly accessed through the Web of Science Database; hence, no ethical clearance procedure was applied separately.

\section{Ölüm Eğitimi ile İlgili Yapılan Çalışmaların Bibliyometrik Analizi: 1970-2021}

$$
\text { Zeynep Funda Sonbul }
$$

Eğitim Bilimleri Anabilim Dalı, Eğitim Bilimleri Enstitüsü, Ankara Üniversitesi, Ankara, Türkiye

Sorumlu Yazar: Zeynep Funda Sonbul, zfundasonbul@gmail.com

Makale Türü: Araştırma Makalesi

Bilgilendirme: Bu makalenin gelişimine değerli görüşleri ile katkı sağlayan mentorüm, Doç. Dr. Raşit Çelik’e teşekkürlerimi sunarım.

Kaynak Gösterimi: Sonbul, Z. F. (2021). A bibliometric analysis of Death Education Research: 1970-2021. Eğitimde Kuram ve Uygulama, 17(1), 98-113. doi: 10.17244/eku.916222

Etik not: Araştırma ve yayın etiğine uyulmuştur. Bu çalışmada, Web of Science veri tabanından erişime açık verilerden yararlanıldı̆̆ı için ayrıca Etik Kurul Onay süreci işletilmemiştir. 


\title{
A Bibliometric Analysis of Death Education Research: 1970-2021
}

\author{
Zeynep Funda Sonbul \\ Department of Educational Sciences, Graduate School of Educational Sciences, Ankara University, Ankara, Turkey
}

ORCID: https://orcid.org/0000-0002-0904-7986

\begin{tabular}{|c|c|}
\hline Abstract & Article Info \\
\hline $\begin{array}{l}\text { Death education should be part of the process, if education means to provide the ultimate } \\
\text { aim of human happiness and general well-being. Death education may help parents in } \\
\text { tough conversations and support children's understanding of death by forestalling } \\
\text { questions in children's minds at this challenging period such as Covid-19 pandemic. This } \\
\text { study aims to analyze the studies on "Death Education" which are indexed in the Web of } \\
\text { Science Core Collection, KCI and SciELO databases within the Web of Science All } \\
\text { Databases by bibliometric method. Since the first study on "Death Education" was } \\
\text { conducted in } 1970 \text { in the reviewed literature, studies from } 1970 \text { to } 2021 \text { were included in } \\
\text { the analysis. Web of Science All Data Bases were scanned using the keywords "death } \\
\text { education", "teaching death and dying", "death and dying course" and "death pedagogy". } \\
442 \text { publications were analyzed according to databases, research areas, years, authors, } \\
\text { document types, journals, countries, languages and visual network maps of } 314 \\
\text { publications were anlalyzed according to co-authorship, co-word and co-citation. Findings } \\
\text { displayed that the most research was conducted in the field of Education and Educational } \\
\text { Research, the most prolific author was Ines Testoni, the most published journal was Death } \\
\text { Studies and the most published year was } 2020 \text {. It was also observed that only two studies } \\
\text { from Turkey took place. Given that studies on Death Education in the national literature is } \\
\text { scarce and this study is the first bibliometric study on Death Education, it is believed that } \\
\text { this study will shed light on future publications on Death Education. }\end{array}$ & $\begin{array}{l}\text { Article History: } \\
\text { Received: } 15 \text { April } 2021 \\
\text { Revised: } 17 \text { June } 2021 \\
\text { Accepted: } 26 \text { June } 2021\end{array}$ \\
\hline
\end{tabular}

Etik not: Araştırma ve yayın etiğine uyulmuştur. Bu çalışmada, Web of Science veri tabanından erişime açık verilerden yararlanıldığı için ayrıca Etik Kurul Onay süreci işletilmemiştir.

Ethical Note: Research and publication ethics were followed. In this study, the data were openly accessed through the Web of Science

Database; hence, no ethical clearance procedure was applied separately. 


\section{Ölüm Eğitimi ile İlgili Yapılan Çalışmaların Bibliyometrik Analizi: 1970-2021}

$\ddot{\mathbf{O z}}$

Eğitim, insan mutluluğunun ve genel refahın nihai hedefine katkıda bulunmaksa, ölüm eğitimi bu sürecin bir parçası olmalıdır. Okullarda verilecek olan ölüm eğitimi, çocukların akıllarındaki soruları cevaplayarak ebeveynlere zor konuşmalarda yardımcı olacaktır. Böylece çocukların Korona pandemisi gibi zor zamanlarda ölüm anlayışını destekleyecektir. Bu araştırmanın amacı Web of Science Core Collection, KCI ve SciELO veri tabanlarında yer alan "Ölüm Eğitimi” ile ilgili yapılan çalışmaların içerik analizi ve bibliyometrik analiz yöntemleriyle incelenmesidir. "Ölüm Eğitimi” ile ilgili ilk makale 1970 yılında yayımlandığı için analize 1970- 2021 yılları arasındaki çalıșmalar dahil edilmiştir. Veriler Web of Science All Databases ‘ta “ölüm eğitimi”, “ölüm ve ölme dersi”, “ölüm ve ölme öğretimi” ve "ölüm pedagojisi” kelimeleri taratılarak toplanmıştır. Derlenen verilerin veri tabanlarına, araştırma alanlarına, yıllarına, yazarlarına, doküman türlerine, dergilerine, ülkelerine, dillerine göre dağılımı analiz edilmiş, ortak yazar, ortak kelime ve ortak atıf analizlerinin görsel ağ haritaları çıkarılmıştır. Konu ile ilgili en fazla çalışmanın Eğitim ve Eğitimsel Araştırma alanında yapıldığı, en üretken yazarın Ines Testoni, en çok yayım yapılan derginin Death Studies, en fazla yayım yapılan yılın 2020 olduğu ortaya koyulmuştur. Derlenen 442 verinin arasında Türkiye'den sadece iki araştırmanın yer aldığı tespit edilmiştir. Ulusal alan yazında Ölüm Eğitimi ile ilgili yapılan çalışmaların bir elin parmaklarını geçmediği ve bu araştırmanın Ölüm Eğitimi ile ilgili yapılan ilk bibliyometrik çalıșma olduğu göz önüne alındığında bu araştırmanın gelecekte Ölüm Eğitimi ile ilgili yapılacak yayınlara ışık tutacağı düşünülmektedir.
Makale Bilgisi

Anahtar kelimeler:

Bibliyometrik analiz, Ölüm

eğitimi, Pandemi

Makale Geçmişi:

Geliş: 15 Nisan 2021

Düzeltme: 17 Haziran 2021

Kabul: 26 Haziran 2021

Makale Türü: Araştırma

Makalesi 


\section{Introduction}

During the period, when COVID-19, a worldwide epidemic, entered human life, death has become a daily issue reported on television as a figure. The fact that children ask more questions reinforces the argument that children should be given a consistent and age-appropriate education about death. Death education may help parents in tough conversations and support children's understanding of death by forestalling questions in children's minds at this challenging period (Friesen, Harrison, Peters, Epp, \& McPherson, 2020, p. 332)

In theory, death education has widely been conducted throughout human history. Previous to being linked to theological representation or formal teaching, by the help of family morals and rites of passage the concepts specific to the relationship between life and death were passed on to the individual by the group. Thus, each individual is incorporated into a symbolic system shared by the community. As law became a science, religion transferred the responsibility of preparing individuals for their socialization, in other words, their social role, to the school system. Recently, school systems, especially in the USA, have taken charge of this task for more than half a century (Fonseca \& Ines, 2012, p. 161).

Herman Feifel's book The Meaning of Death (1959) based on the death awareness movement put death education on the agenda unofficially. He and other scholars have noted that the topic of death became a "taboo" in the twentieth century, and have suggested that it is necessary for individuals to accept their personal death for a worthwhile life. Scientific studies on death attitudes were pioneered by Feifel by pointing out the multidisciplinary nature of the field. Other pioneers have focused on more specific issues such as dying people's care and experiences of grief were studied by other scholars (Wass, 2003a, pp. 211-212). Education in general, is an important tool for communicating knowledge and facilitating insights. Knowledge has a great influence on developing and changing attitudes and values. Education, which also directly affects attitudes and values, helps identify, empower or change them (Wass, 2003b, p. 26). Death education should be part of this process, if education means to provide the ultimate aim of human happiness and general well-being (Crase \& Crase: 1985, p. 346). Bensley (1975) argued that death education had many things in common with sex education, and that several myths, taboos, and fears transferred from generation to generation related to death education, as well as sex education (Bensley, 1975, p. 2).

Concealing death in a veil of mysticism will not alter the fact that death is the end of the road for every living being. By the aid of death education it would be easy to place the experience of dying in the ordinary world of human experience as significant part of the life circle. The benefit of death education is to gain knowledge to facilitate the study of opportunities and to help advance lifestyles useful for health and happiness (Silverman, 1987, p. 36). The primary function of death education is to deeply think and feel the meaning of life in many relationships, to help the maturation of values. Going beyond the fear and avoidance of death, common in many cultures can teach people to accept dying as a convenient climax of life. In order to achieve this, topics about mortality should be discussed willingly and it is apparent that death education can provide this (Morgan \& Morgan, 2001, p. 1).

Mirroring the broad-based academic beginnings, death and dying courses were established at Clark University by Robert Kastenbaum, at the University of Minnesota by Robert Fulton, at the University of Maryland by Dan Leviton and at Yale University by James Carse (Wass, 2003a, p. 211). Therefore, the first formal education related to death education in the United States started at the higher education level, and then spread to the secondary and primary levels. Again, the first academic researches on death education were conducted in the United States. The first publication on death education registered in the Web of Science database was "Death Education - Adult Education in the Face of a Taboo". It was written by J. A. Farmer and published in Omega - Journal of Death and Dying in 1970. Studies on death education in Turkey are fairly rare.

The first study on death education in national literature was "The impact of death on children and death education". This article was written by Mustafa Köylü in 2004 and published in the Journal of the Faculty of Theology of Ondokuz Mayis University. The article focused on children's understanding of death, the impact of death on children, and various methods of death education (Köylü, 2004). The first graduate study on death education was a doctoral dissertation and was conducted by Fuat Tanhan in 2007 at Ankara University Graduate School of Educational Sciences in the field of Guidence and Counselling. "The effects of coping with death anxiety education programme on death anxieties and psychological well-beings" was an experimental study that examined the effect of the education program to deal with death anxiety developed on students' death anxiety and psychological well-being levels. In the study, the pre-test final test control group pattern, which is often used in experimental studies, was used (Tanhan, 2007). The study was later published under the title of "The effects of death education on death anxieties and psychological well- beings" in YYÜ Journal of Education Faculty in 2013. Another graduate study related to death education was a doctoral dissertation and was conducted by Figen Inci in 2008 in the Department of Psychiatric Nursing of the Institute of Health Sciences of Hacettepe University: "Effects of death education on anxiety, depression and attitudes of nurses". The study was conducted as a pre-test final test pattern intervention study in a single group to 
assess the impact of death-related education on nurses' death-related anxiety, death-related depression and attitudes towards the terminally ill patient (İnci, 2008). The study was later published as an article in the Anatolian Journal of Psychiatry in 2009 with Fatma Öz as a co-author. These two doctoral theses were published as a book entitled "Death Education" in 2009 by Fuat Tanhan and Figen Arı İnci. The last study on death education was an article entitled "Death education at school for counselor who work in elementary school" that aimed to investigate the psychological counselors' perceptions of competence before and after attending the death education seminar (Bölükbaş1-Macit \& Tümlü, 2019).

The fact that there are very few studies in the national literature about death education, it is important to bring forth useful information related to general fabric of the field. Therefore, the purpose of this study was to conduct a bibliometric analysis of the studies related to "death education". Bibliometric methods provide the researcher with helpful information about the field of research, such as who are the leading authors, which are important publications, and what is the basic structure of the field. Bibliometric methods can be used in independent bibliometric analysis articles, as well as to provide additional information in structured literature reviews. Bibliometric methods that allow the researcher to look behind events and base their views on the collective views of scientists working in this field, when used correctly, can provide increased objectivity in literature reviews (Zupic \& Cater, 2011, p. 437). Given the lack of studies on death education in the national literature, it is quite obvious these kinds of researches are required.

It is crucial to reveal the general trends, author collaborations or citation networks of international publications in the field to shed light on future work in the field. Taking into account bibliometric methods contribute in identifying workspaces and missing fields (Özteke Kozan, 2020), this study is thought important as being the first bibliometric analysis on death education.

In this study, it was aimed to analyze the studies on "Death Education" indexed in the Web of Science Core Collection, KCI and SciELO databases within the Web of Science All Databases, by bibliometric method. Since the first study on "Death Education" was conducted in 1970, studies from 1970 to 2021 were included in the analysis. The research questions in this study were as follows:

1. How are the studies on "death education" distributed according to databases?

2. How are the studies on "death education" distributed according to research areas?

3. How are the studies on "death education" distributed by year?

4. How are the studies on "death education" distributed according to the authors?

5 . How are the studies on "death education" distributed according to document types?

6. How are the studies on "death education" distributed according to journals?

7. How are the studies on "death education" distributed by country?

8. How are the studies on "death education" distributed by language?

9. How are the visual mapping of studies on "death education" distributed according to

a. co-authorship?

b. co-occurence of keywords?

c. co-citation?

\section{Methodology}

In this study, studies on death education were examined using bibliometric analysis and content analysis methods a kind of systematic compilation methods. "Content analysis can be grouped under three sub-headings: "meta-analysis, metasynthesis (thematic content analysis) and descriptive content analysis" (Çalık \& Sözbilir, 2014, p. 34). Bibliometric analyses are also one of the methods used in systematic compilation studies, as they quantify the general situation of publications related to a particular discipline or field (Özteke Kozan, 2020, p. 6). Descriptive content analysis includes selecting the literature on the subject to be investigated using certain criteria, uncovering and interpreting descriptive data, regardless of whether it is quantitative, qualitative or mixed. Here, the main goal is to show how the subject that needs to be studied is handled by researchers based on descriptive data and how this situation tends over time (Bellibaş \& Gümüş, 2018, p. 511).

Bibliometric methods use a quantitative approach help to describe, asses, and observe published research. The quality of reviews are enhanced due to these methods having the prospective to put forward a systematic, pellucid and 
repeatable review procedure. The other benefit of bibliometric methods is to guide the researcher to the most effective studies and to map the research area without subjective prejudice (Zupic \& Cater, 2015, p. 429).

By means of bibliometric analysis, it is possible to learn what the general trends are in any discipline, how the authors in the field cooperate with each other and the general status of the publications that receive citation. Bibliometric analysis and general trends of publications can also be revealed with data analysis programs that offer different visual maps (Özteke Kozan, 2020, p. 6). Science mapping -a quantitative approach based on bibliometric research methods is used for revealing the structure and development of scientific disciplines and is increasingly used. The goal in scientific mapping is to create a representation of the structure of the research field by dividing elements, that is, units of analysis (documents, authors, journals, words) into different groups. Visual representation of the appearing classification is created by using visualization (Zupic \& Cater, 2015, pp. 429, 431).

The likeness between analysis units is commonly calculated by counting the times when the two units exist together in the documents. In addition, direct connection can be used to acquire relationships between units. The relationship between units can be represented as a graph or network in which the units are nodes and the relationships between them represent an edge between two nodes, i.e. different bibliometric networks can be created using the relationships between units of analysis (Cobo, Lopez- Herrera, Herrera- Viedma, \& Herrera, 2011, p. 1384). Bibliometric methods of which the usage has been proliferating in recent years, grant researchers to base their conclusions on aggregate bibliographic data supplied by other scholars engaging in the field who declare their views through citation, collaboration, and writing. Information on the framework of the field, social networks and current interests can be revealed by accumulating and analysing data (Zupic \& Cater, 2015, p. 430).

In this study, VOSviewer, a computer program that can be used free of charge to create and display bibliometric maps, was used. Though SPSS and Pajek are usually used for bibliometric mapping, Vosviewer gives due consideration to the graphical representation of bibliometric maps. Vosviewer, also enables researchers to exhibit large bibliometric maps so that it can be read without difficulty (Eck \& Waltman, 2010, p. 536). The Vos mapping technique creates a two-dimensional map in which the elements are placed to reflect as accurately as possible the similarities of the distance between any pair of elements. "The idea of the Vos mapping technique is to minimize a weighted sum of Square Euclidean distances between all pairs of elements through an optimization process" (Cobo et al, 2011, p. 1390).

\section{Data Sources}

In the first phase of the research, Web of Science All Data Bases were scanned using the keywords "death education", "teaching death and dying", "death and dying course" and "death pedagogy" and a total of 627 studies were reached. The scans were started on 01.02.2021 and the last scan was carried out on 08.02.2021. Abstracts from the studies were read and non-related studies were extracted, and a total of 442 studies were included in the analysis.

\section{Data Analysis}

Bibliometric and descriptive content analysis were used in the analysis of the data in this study. 442 data were retrieved from Science Citation Index Expanded (SCI-Expanded), Social Science Citation Index (SSCI), Arts \& Humanities Citation Index (A\&HCI), Conference Proceedings Citation Index - Science (CPCI-S), Conference Proceedings Citation Index - Social Science \& Humanities (CPCI-SSH), Emerging Sources Citation Index (ESCI). All of these indexes are found in the Core Collection of Web of Science. Korean Journal Database (KCI), Russian Science Citation Index and SciELO Citation Indexes are also part of Web of Science. The 442 studies were subjected to content analysis whereas, only 314 studies were subjected to science mapping. Visual mapping was analyzed in three categories: co-authorship, co-occurence of the keywords, and co-citation.

\section{Distribution of the studies according to databases}

\section{Findings}

$70 \%$ of data was retrieved from the Core Collection of Web of Science database. These are Science Citation Index Expanded (SCI-Expanded),Social Science Citation Index (SSCI), Arts \& Humanities Citation Index (A\&HCI), Conference Proceedings Citation Index - Science (CPCI-S), Conference Proceedings Citation Index - Social Science $\&$ Humanities (CPCI-SSH), Emerging Sources Citation Index (ESCI). Korean Journal Database (KCI) where $28 \%$ of data was obtained provides English and Korean articles from multidisciplinary journals. KCI is administered by the National Research Foundation of Korea and contains bibliographic information for scientific literature published in Korea. SciELO, where $2 \%$ of the data was obtained, provides scientific literature in the sciences, social sciences and arts and humanities, published in leading open access journals in Latin America, Portugal, Spain and South Africa. The Russian Science Citation Index, which is part of the Web of Science, submitted 1 publication but was not 
included in the study because the article presented was not directly related to death education. In brief, 70\% (314 studies) of the data was compiled from Web of Science (WoS), 28\% (122 studies) from KCI and 2\% (6 studies) from Scielo. The databases from which 442 studies were compiled is shown in Figure 1.

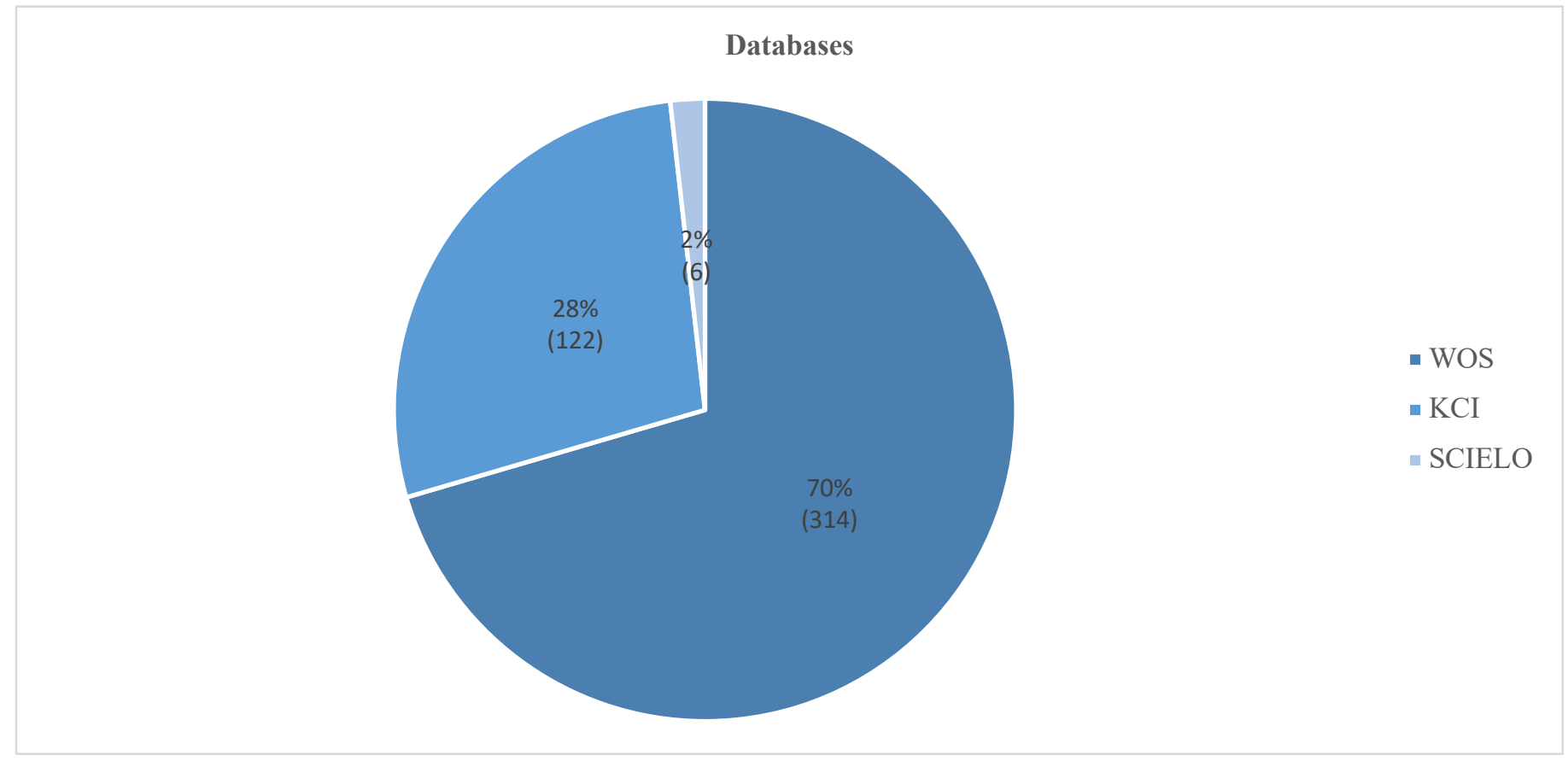

Figure 1. Distribution of the studies by databases

\section{Distribution of the studies according to research areas}

It can be seen from Figure 2 that the majority of the studies were conducted in the field of "Education and Educational Research". "Education and Educational Research" was followed by "Psychology", "Social Issues", "Biomedical Social Sciences", "Social Sciences other topics", "Geriatrics Gerontology", "Religion", "Public Environment and Occupational Health", "Health Services Social Sciences" and "Nursing". Figure 2 below shows the top 10 research fields.

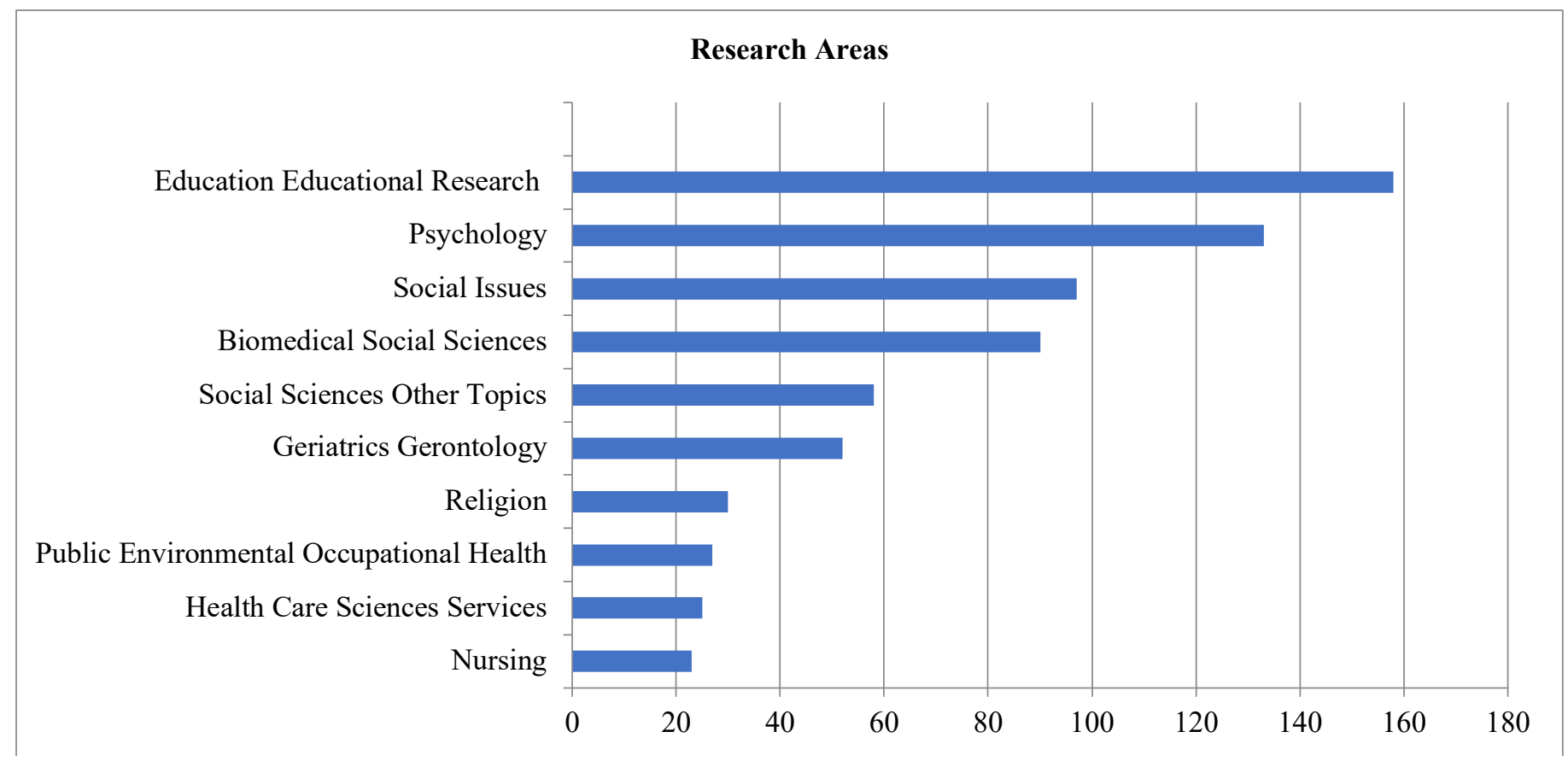

Figure 2. Distribution of the studies according to research areas 


\section{Distribution of the studies by years}

Table 1. The first 5 years with the most publications

\begin{tabular}{|lll|}
\hline & Year & Number \\
\hline 1. & 2020 & 30 \\
\hline 2. & 2016 & 26 \\
\hline 3. & 2015 & 25 \\
\hline 4. & 2019 & 25 \\
\hline
\end{tabular}

The maximum 5 years of publications in the 50-year period (1970-2021) is demonstrated in Table 1 . When the figure (Figure 3) showing the distribution of studies on "death education" by year was examined, it is understood that the first study on "death education" was conducted in 1970. When the 70s were examined, it is seen that there were slightly few studies at the beginning of the 70s. The studies gained momentum in 1975. There were 9 studies in 1976, 16 in 1977, 9 in 1978, and 11 studies in 1979. In the early 1980s $(1980,1981,1982,1983)$ the increase in the number of studies related to "Death Education" shows that the demand for studies related to "Death Education" is growing. However, studies in this field had declined as of 1984. This decline continued into the 90s and maintained until the early 2000s. Overall, since 2003 the number of the studies gradually increased, whereas in 2007, the number dropped to 2. As can be seen from the figure the least publication occured in 1970, 1973, 1998, 2001 and 2002 with one publication and the number of the studies published in a year reached a peak in 2020 with 30 publications.

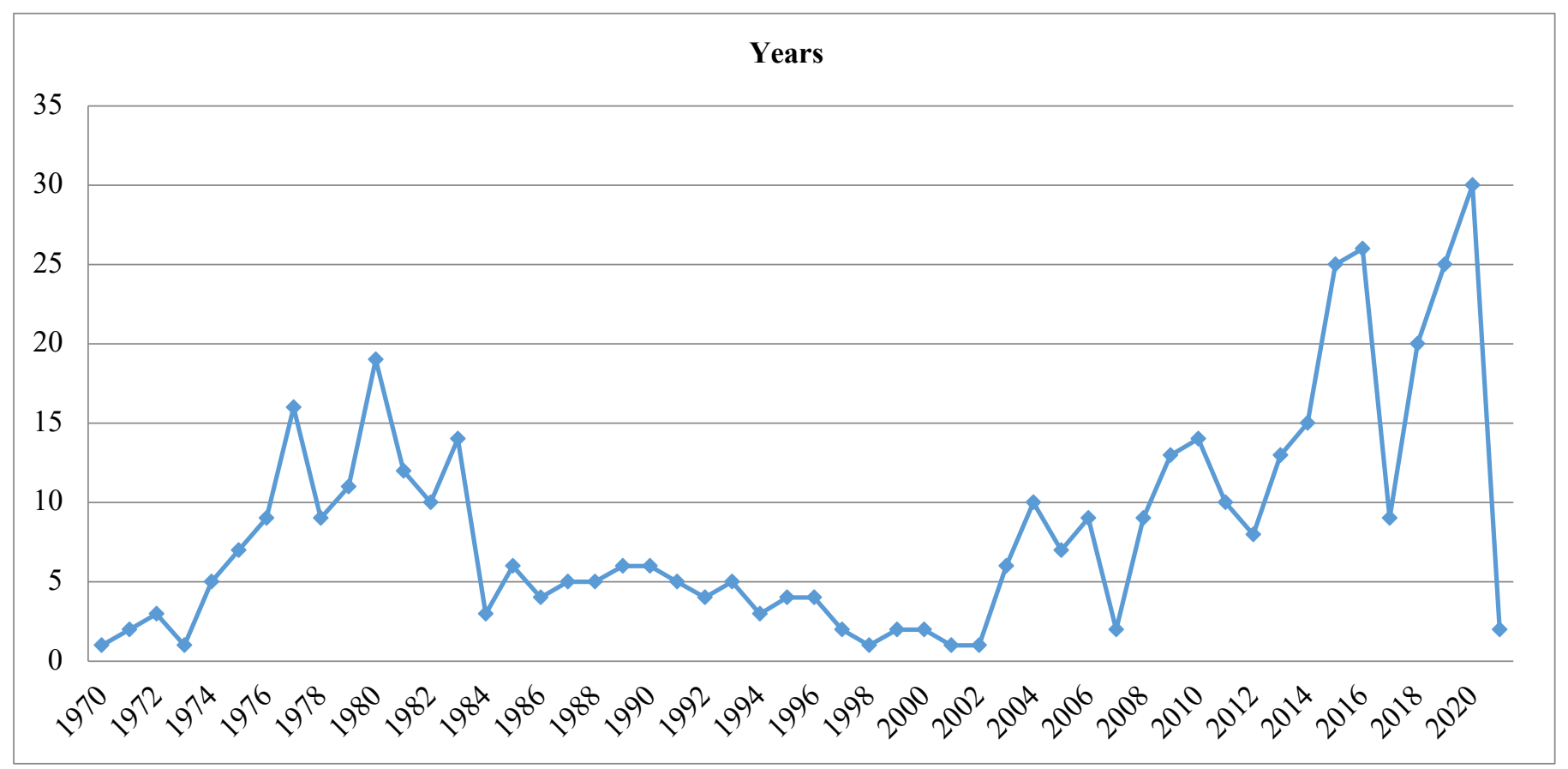

Figure 3. Distribution of the studies over the years

\section{Distribution of the studies according to authors}

Figure 4 displays the distribution of the studies on "Death Education" by authors. It is understood that the author who contributed the most to the field with 12 studies is Italian researcher Ines Testoni. Testoni was followed by American researchers Dickinson with 11 and Crase with 10 studies, Korean researcher Jung Jae Geol with 8 studies, Spanish researchers Gascon, Herrero and American researcher Leviton with 7 studies, Italian researcher Ronconi and American researcher Wass with 6 studies and Korean researcher Kang Sun-Bo with 5 studies. Figure 4 below exhibits the top ten scholars in the field. 


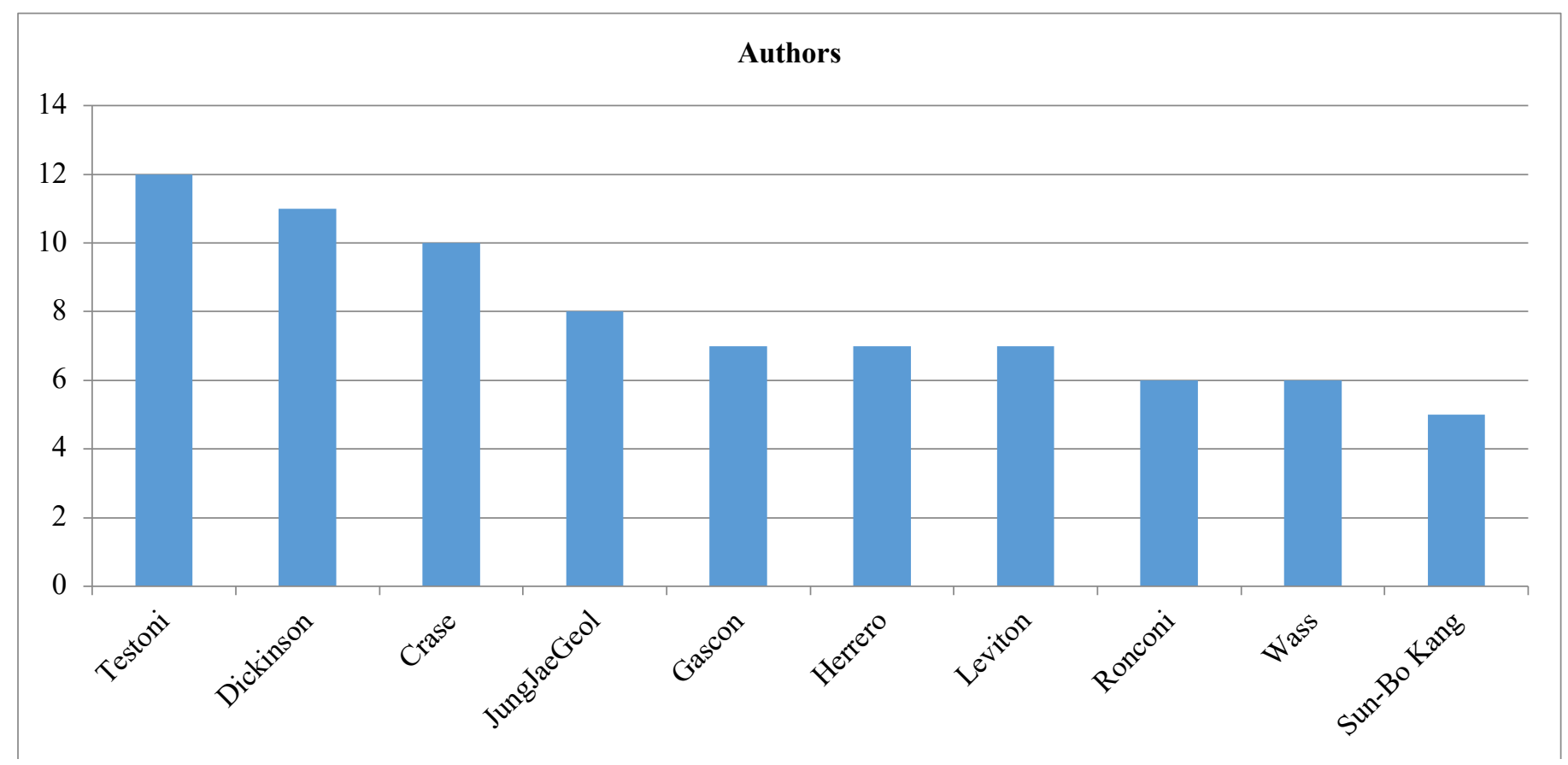

Figure 4. Distribution of the studies according to authors

\section{Distribution of the studies according to document types}

A total of 442 publications were diverse in type. The most commonly used type of document was articles (368) followed by reviews (35). The remaining types were abstracts (17); meetings (13); early access (10); editorial (9); letters (5) and biography (1).

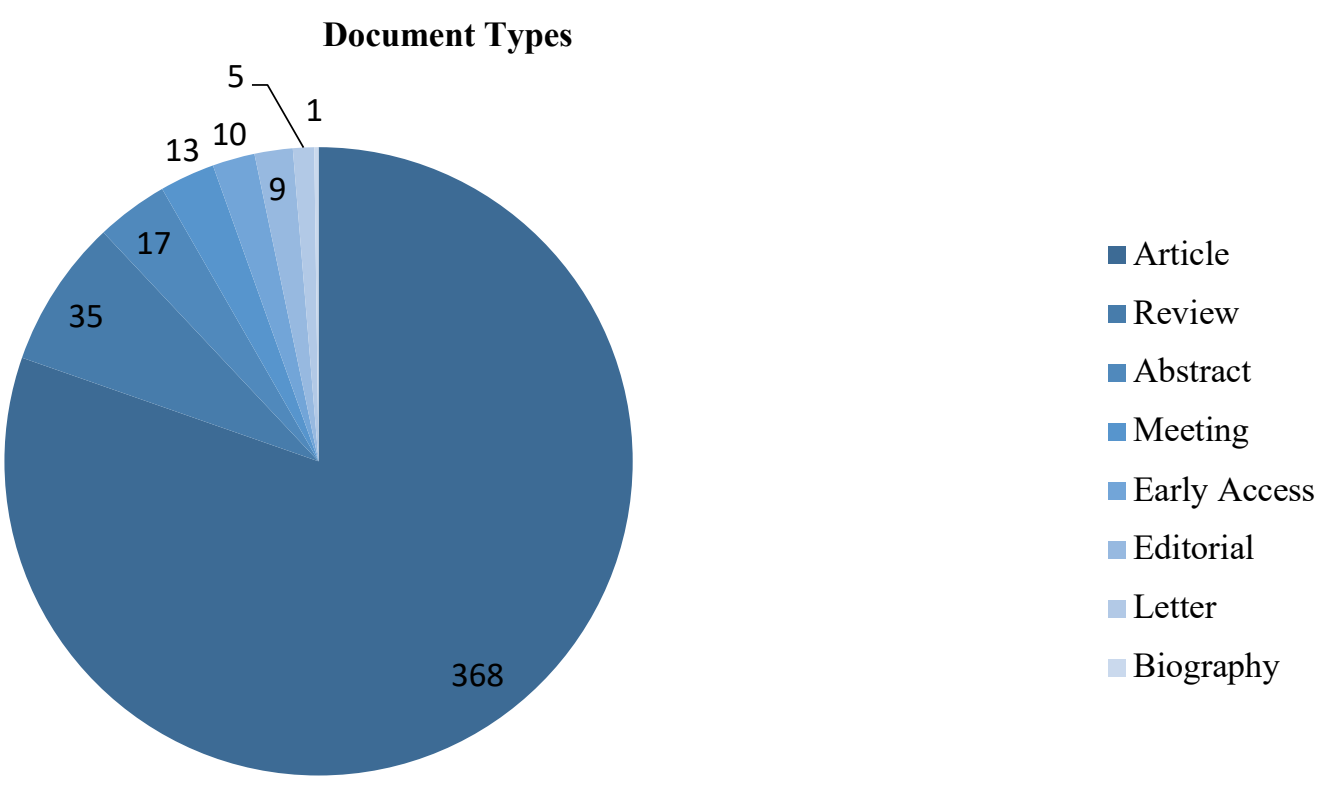

Figure 5. Distribution of the studies according to document types

\section{Distribution of the studies according to journals}

Figure 6 exhibits ten journals that published the most "Death Education" articles from 1970- 2021. Death Studies published the highest number of researches with 51 studies. Death Education and Omega Journal of Death and Dying came after with 43 and 38 studies, respectively. As can be seen from the figure below there were 3 Korean journals among the most published journals. 


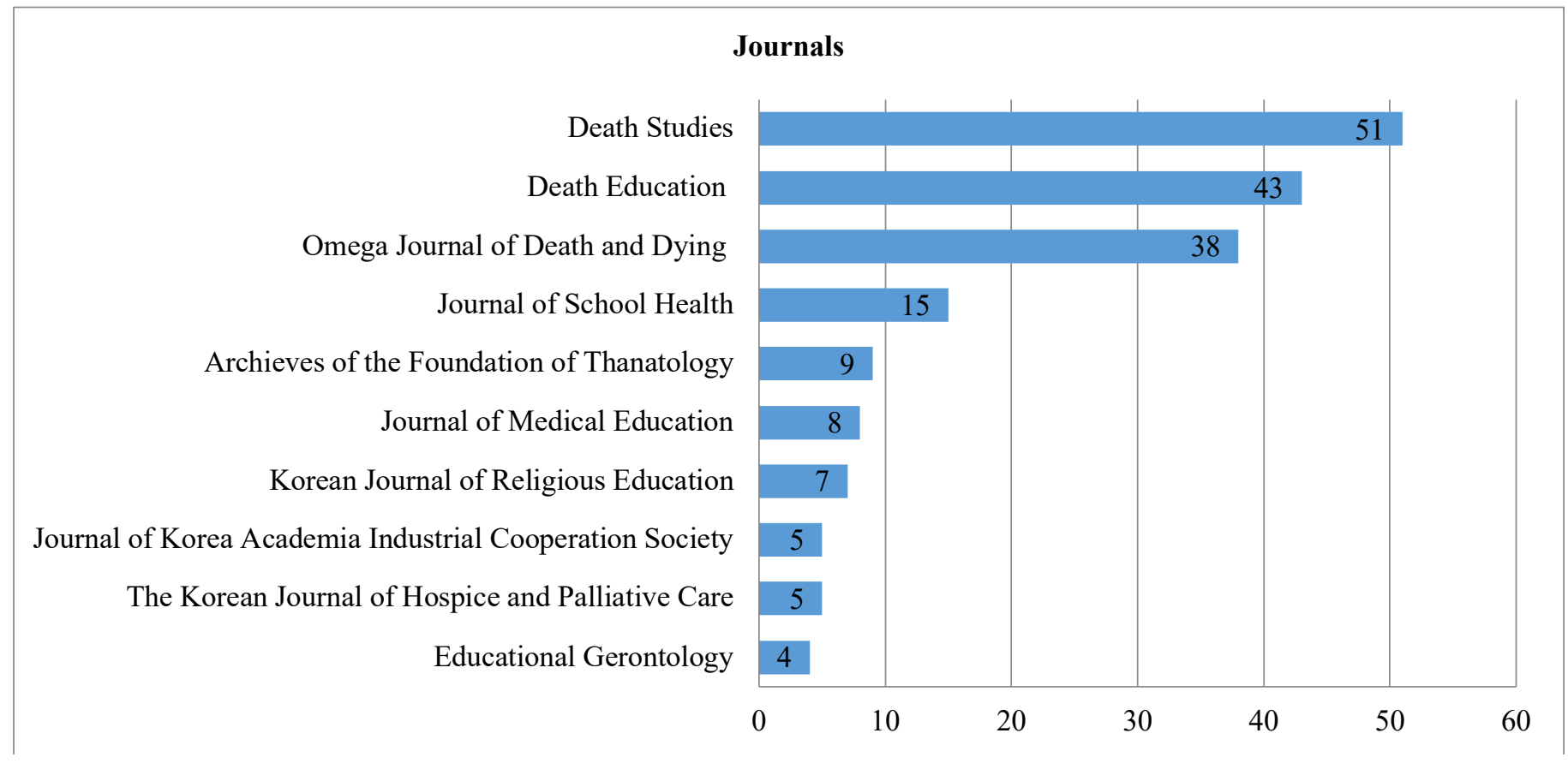

Figure 6. Distribution of the studies according to journals

\section{Distribution of the studies according to countries}

When Figure 7 examined it is seen that the country with the most publications was the United States with a decidedly different margin of 189 publications. It was follwed by China (19), Spain (18), Israel (12) and Italy (12), respectively.

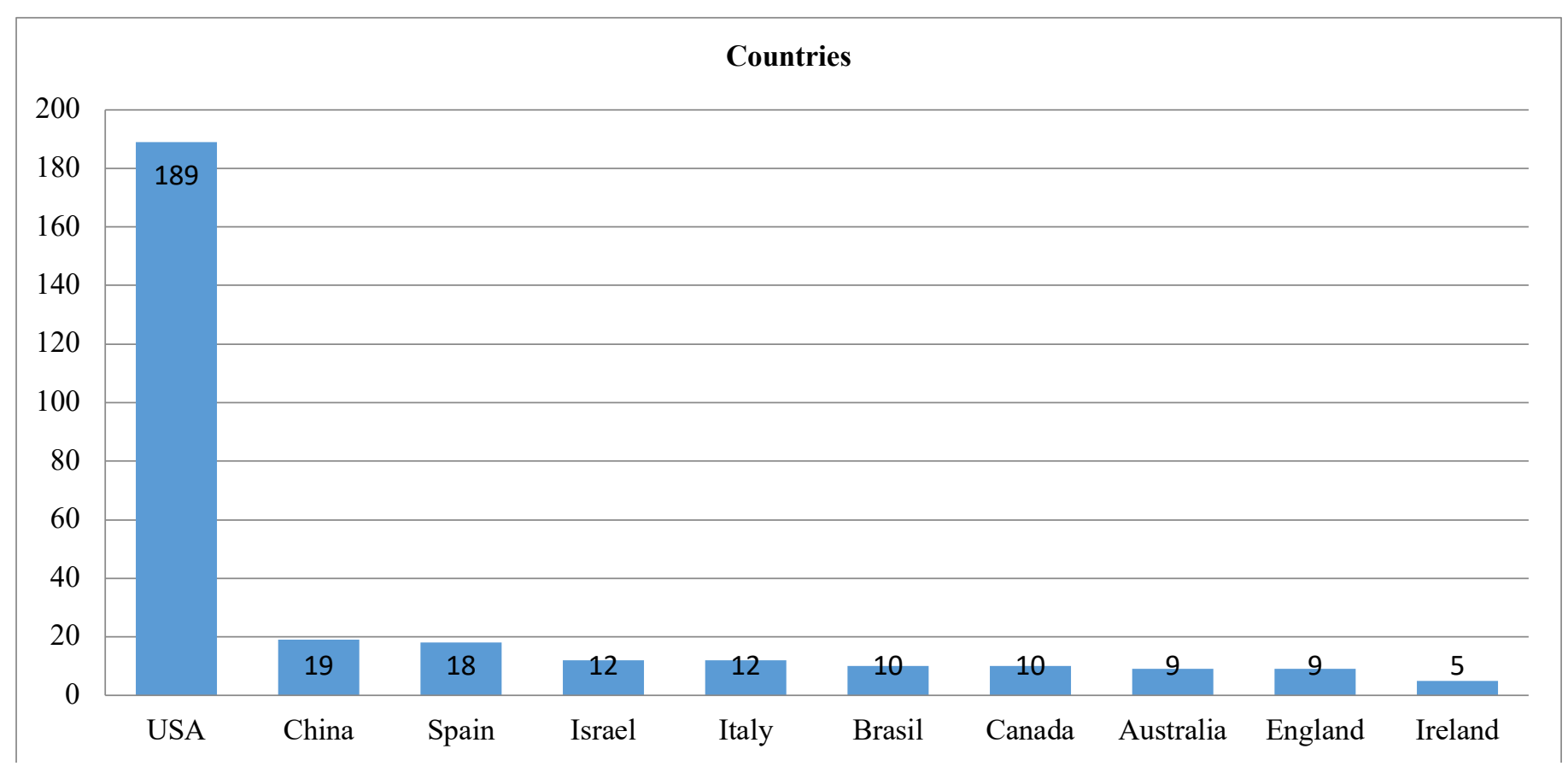

Figure 7. Distribution of the studies according to countries

\section{Distribution of the studies according to languages}

The language most used was English regarding to the language used in the publications. While 300 of the 442 studies was English, 118 of them was Korean. The other 5\% consisted of Spanish (12), Portuguese (6), German (2), Turkish (2), Chinese (1) and Japanese (1). 


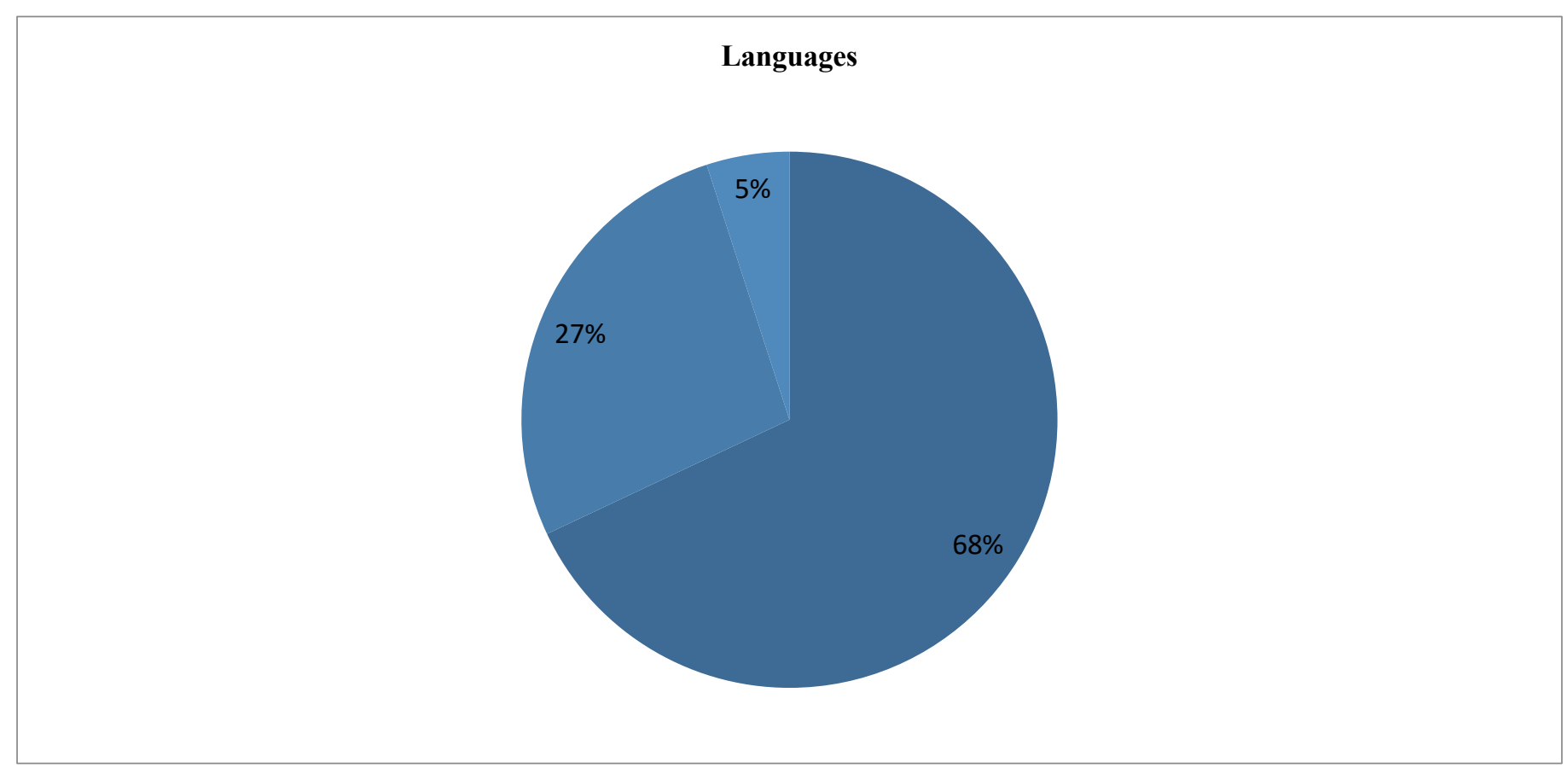

Figure 8. Distribution of the studies by languages

\section{Visual mapping of the studies}

The 442 studies that were the basis of this research were compiled from the Web of Science Core Collection and KCI and SciELO databases within the Web of Science database. Although the content analysis of this research was carried out with 442 studies retrieved from all databases, the visual mapping of the research was technically done with 314 studies in the Web of Science Core Collection. The visual mapping of these 314 studies was analyzed in three categories: co-authorsip, co- word and co-citation.

\section{Co-authorship}

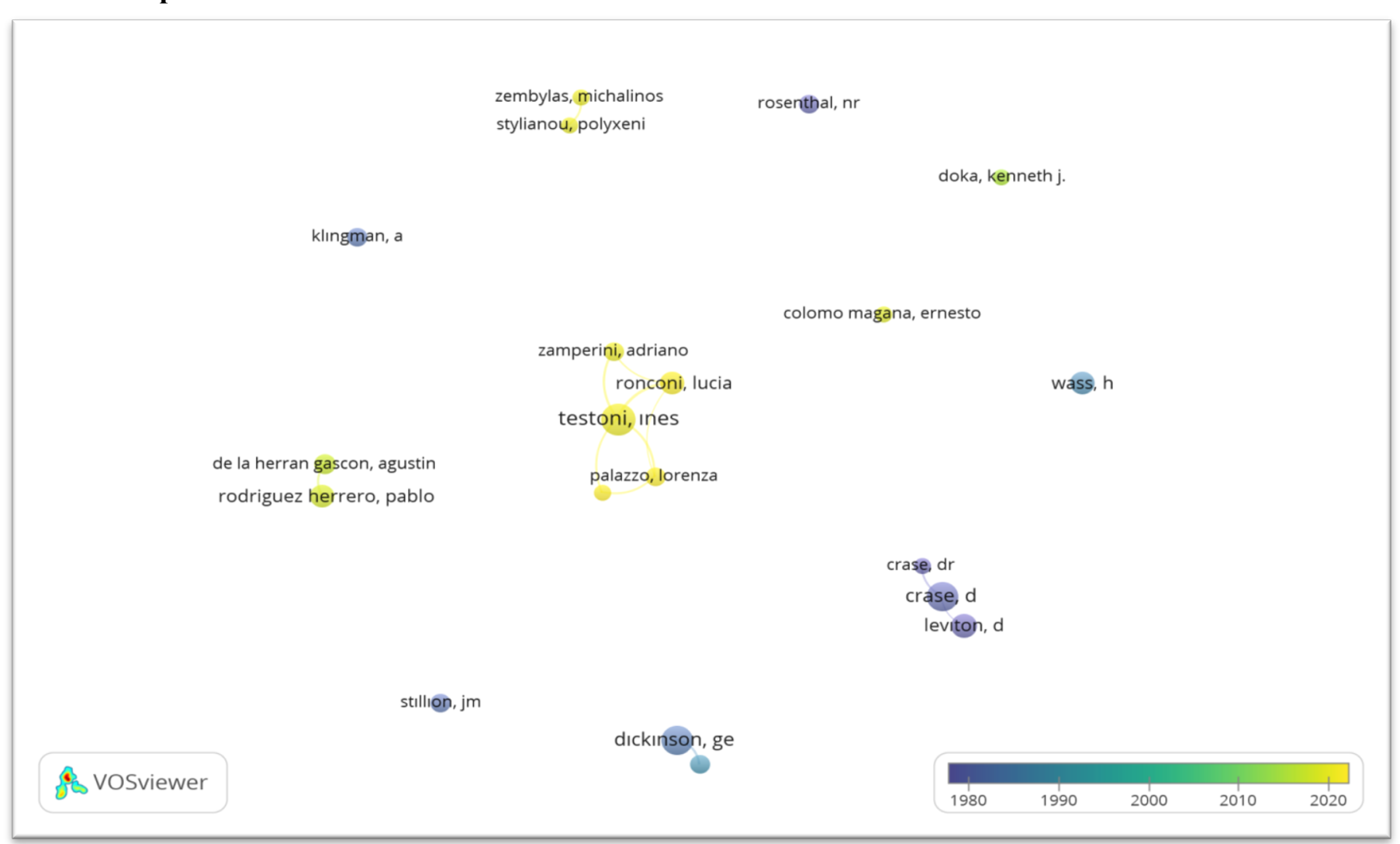

Figure 9. Co-authorship 
To analyze the co-authorhip of the studies conducted on Death Education, 3 was taken as a minimum number of publications. 20 authors from 512 met this criterion. For each of the 20 authors, the total strength of co-authorship links with other authors was calculated and authors with the largest total connectivity were selected.

When the visual map in Figure 9 examined, it is understood that the authors usually work separately or in small groups and it can be said that group work has recently come to prominence. It is clear that while early researches had been done individually for instance the works of Wass, Klingman, Stillion, Rosenthall and Doka, the recently researches conducted by Gascon and Herrero; Testoni, Ronconi, Zampereni and Palazzo; Stylianou and Zembylas were an example of collaboration. In other words, the importance of author cooperation rose in the studies on Death Education. Studies by these authors revealed that they carried out studies on death education on the basis of schools, classrooms, teachers and students.

\section{Co-occurence of keywords}

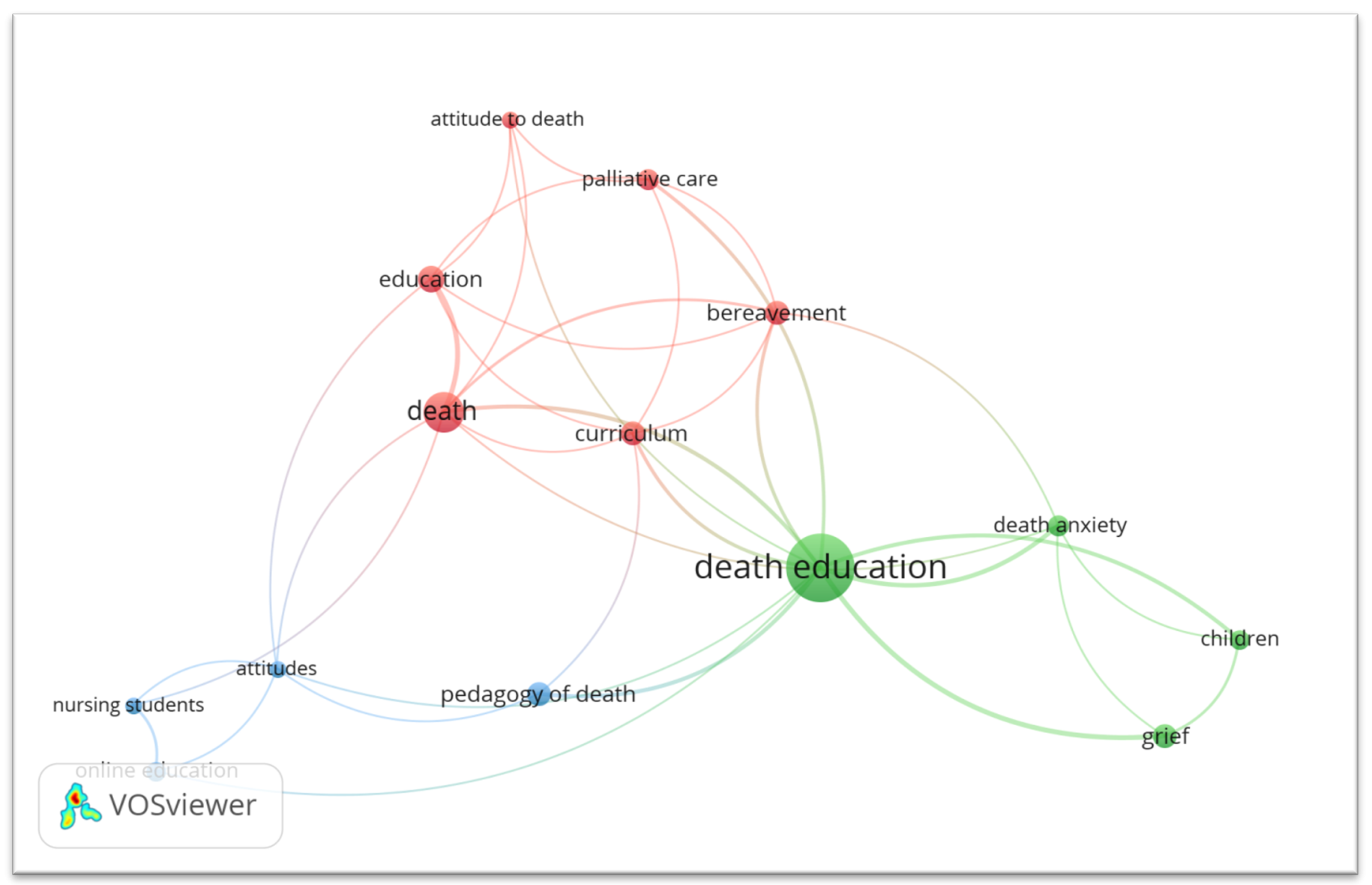

Figure 10. Co- occurence of keywords

When the co-occurence keyword analysis breakpoint (minimum repetition) was taken as 3, 14 of the 254 keywords met the threshold. For each of the 14 keywords, the total power of the co-occurence links with other keywords was calculated and the keywords with the greatest total link strength were selected.

The size of the circle shown in the visual map in Figure 10 shows the intensity of use of the keyword, the colors indicate the clustering of keywords, and lines are also collected. The words for Death Education were grouped into three sets: green, red and blue. At the center of the map the term "Death Education" (50) took place. It is understood that the word death education followed by "death" (17), "education" (8), and "bereavement" (6). The link of the word "death education" was 11 . The link of the second-placed word "death" was 8 , while the link of the thirdplaced word "education" was 6 . The words "online education" and "nursing students" appeared in the blue set and the word "attitude to death" in the red set indicate the words with the lowest prevalence. 


\section{Co- citation}

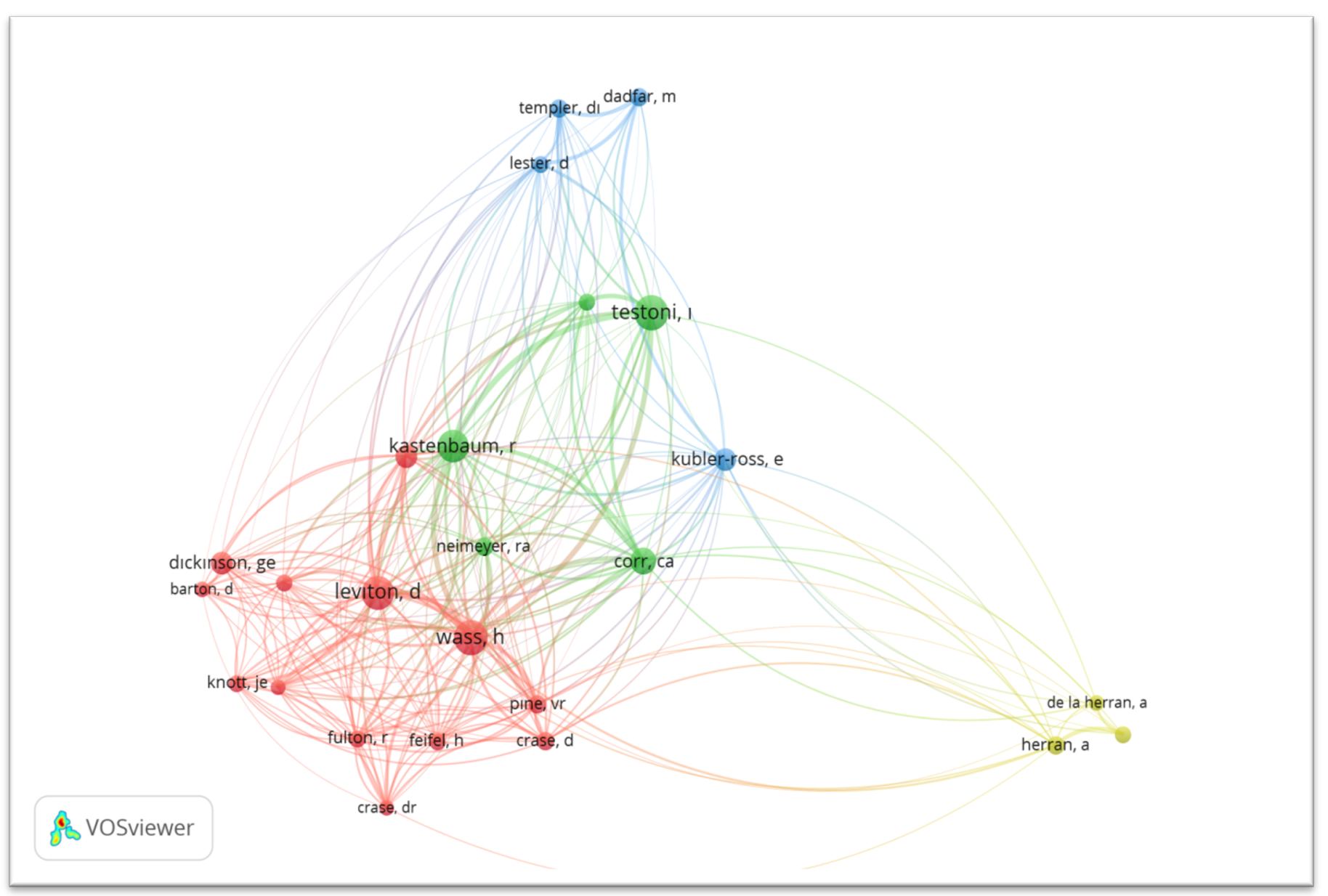

Figure 11. Co- citation

Of 3876 authors 25 authors met the threshold when a minimum citation number was taken as 20 in analysis of the studies conducted on Death Education. For each of the 25 authors, the total strength of co-authorship links with other authors was calculated and authors with the greatest total link strenght were selected. Analyzing the co-citation network in Figure 11 shows that the clusters were four different colors - red, blue, green, and yellow. The size of the circles is the plurality of the spreads that are attributable. The map shows that blue, red, and green circles are larger, so it's clear that the authors who get the most citation are the authors in these circles. The yellow set, whose circles are smaller and farther than other sets, is apparently receiving less attribution than other clusters. Elisabeth Kübler-Ross was at the center of the blue cluster. The red cluster has an intense citation flow both within itself and with other, $\mathrm{H}$. Wass was the author who received the highest citation with 107. Wass was followed by Testoni with 105, D. Leviton with 99, R. Kastenbaum with 86 and C. A. Corr with 61 citations. These five authors were the most cited authors.

\section{Conclusion, Discussion, and Recommendations}

In this research, publications on "Death Education" in the international literature were presented using content analysis and bibliometric analysis methods. At the first stage, 442 publications related to "Death Education" in Web of Science All Databases were analyzed according to databases, research areas, years, authors, document types, journals, countries and languages. In the second phase, the co-authorship, co-occurence of keywords and co-citation maps of 314 publications related to "Death Education" in the Web of Science Core Collection were created using the bibliometric analysis method.

A bibliometrics study on "Death Education" in the international literature was conducted by Martinez-Heredia and Moreno in 2020. "Impacto de la producción científica acerca de la educación para muerte: Revisión bibliométrica en Scopus y Web of Science" (Impact of scientific production on death education: bibliometric review in Scopus and Web of Science) was written in Spanish. The studies from 2015 to 2019 on death education were compiled from Scopus and Web of Science databases. The data was analyzed according to amount of publications of the last five years, and by natural year, type of document, indexing area, periodical publications, internationalization 
of research, publication institution, authorship of publication, publications with the greatest impact and keywords (Martinez- Heredia \& Moreno, 2020). In the national literature, there is no bibliometric analysis on "Death Education". It is believed that this research will make a significant contribution to the field in terms of guiding researchers who want to conduct research related to Death Education.

According to the findings of the research, while 314 of 442 publications were included in the Web of Science Core Collection, KCI and SciElo came after with 122 and with 6 respectively. A publication in the Russian Science Citation Index, part of the Web of Science database, was not included in the analysis since it was not directly related to Death Education. The fact that only one publication is included in the RSCI shows that the field of death education in Russia has not yet developed.

When the findings of the research areas were examined, it was determined that the majority of the research was carried out in the field of Education and Educational Research. Given that the field of education covers formal education levels (elementary, secondary, high school), informal educational institutions (adult courses, public training centers etc.) and different disciplines (psychology education, nursing education, geriatrics etc.) it can be said that this is an expected result.

The first article related to "Death Education" was "Death Education-Adult Education in Face of a Taboo" written by J. A. Farmer and published in "Omega- Journal of Death and Dying" in 1970. As the work on Death Education gradually increased, it gained momentum in 1974 and this momentum continued for a ten-year period until 1984. One of the reason of the growing interest in death in the 1960s and 1970s, is the social climate of the United States. This was the period when bloody Vietnam War and those who lost their lives in that war was intense, interest to students subjectivism, Eastern religion, genocide, the dangers of nuclear war was high, alternative life styles and behaviors of women and ethnic groups in terms of social and legal matters, both as individual freedom of expression was supported by a large segment of people. It was a period when the elderly population increased, the average age rose, scientists understood the merits of the biology of aging and dying; events such as Karen Ann Quinlan and other victims of vegetative life led the medical community to reconsider the definition of death again (Aiken, 2001, p. 28). In addition, an international meeting of Death and Dying leaders was held in the United States in 1974, and at the end of this meeting, the International Work Group for Death Education (IWGDE) was established. Also in 1976, the Association for Death Education and Counseling (ADEC) was established in the United States (Brennan, 2014, p. 6). It is apparent that the period between 1997 and 2002 was the least prolific period of studies on "Death Education". Only 9 studies were conducted during this six-year period. The studies, which gained momentum again in 2003, reached a peak with 30 studies in 2020 .

When the studies on "Death Education " were evaluated according to authors, it was determined that the studies in the early years were carried out by researchers in the United States, where the concept of death education emerged and developed. Among the ten authors who did the most research were American scholars Dickinson, Crase, Leviton, and Wass -the pioneers of death education. Since the 2000s, European researchers started to pay attention to death education. Especially Italian and Spanish writers made a great contribution in this field, both in their native language and in English. A notable feature of these authors is that they signed co-authored works. In other words, these authors gave importance to cooperation and put forward collaborative work. Among the ten most published authors, Italian Testoni was the most prolific author with 12 publications, while another Italian writer, Ronconi, was among the most prolific authors with 6 publications. Moreover, Testoni and Ronconi had five collaborations with other authors. Two other writers, both prolific and cooperative, were the Spaniards Gascon and Herrero. These two authors also managed to become one of the ten most published authors with seven works. Similarly, Gascon and Herrero had eight collaborations together. There were two Korean researchers among the ten most published authors on "death education". JungJaeGeol had eight and SunBo Kang had five works. There were only four Turkish researchers with two articles.

According to the 442 types of research documents conducted on "Death Education", the articles took the first place with a ratio of $80 \%$. $20 \%$ were abstracts, reviews, early access, meetings, editorial, letters and bibliographies. Because the Web of Science Database indexes scientific journals, data on books or book chapters related to "Death Education" was not available in the database. But some of the editorial writing was about book introductions.

Death Studies, one of the leading journals in the field, was the most widely published journals about "Death Education". The journal, which was published under the name "Death Education" for seven years between 1977 and 1984, has continued to publish under the name "Death Studies" since 1985. 43 of the 94 studies were published in "Death Education" and 51 in "Death Studies". Omega - Journal of Death and Dying", which ranked second in the most published journals with 38 studies, began its publication life in 1970. The first article on "Death Education " was also published in Omega Journal of Death and Dying in 1970. The presence of five Korean journals among the top ten 
most published journals is an indication that research on "Death Education" is given importance in Korea. After 2002 Korea witnessed a growing signal in the number of articles related to "Death Education".

Looking at the most published countries on" Death Education", it is obvious that the United States was decidedly ahead with 189 studies. This number is expected to be quite high, given that the concept of "Death Education " was pioneered in the United States, grew up and developed there. The number of other countries that followed the United States was quite close to each other. This indicates that other countries are unlikely to surpass the United States, at least in the near future.

When examining the language of publications of studies on" Death Education", it is seen that $68 \%$ of the researches was conducted in English. English was followed by Korean with 27\%. Since the 2000s, there has been an interest in studies related to death education in Korea, and this interest has steadily increased. 117 of the 122 studies compiled from the KCI database was Korean. Researches written in Korean made a valuable contribution to their national literature, however they couldn't obtain international recognition. Turkish, German, Chinese and Japanese consisted of the remaining 5\%. Findings displayed that the number of studies regarding "Death Education" in Turkey was scarce. Moreover, there was not any article written in English which was conducted by Turkish researchers.

When the bibliometric analysis of 314 studies in the Web of Science Core Collection was examined, the coauthorship network map showed that while studies were conducted individually in older periods, the number of studies conducted in collaboration has increased since the 2000s. According to the co-authorship network map, 11 studies in which Testoni was the first author were conducted in a wide collaboration. It was established that the study "The "sick-lit" question and the death education answer. Papageno versus werther effects in adolescent suicide prevention" was carried out with 7 authors; "Before I die I want to ...": An experience of death education among university students of social service and psychology" was carried out with 7 authors; "Psychodrama and moviemaking in a death education course to work through a case of suicide among high school students in Italy" was carried out with 6 authors; "Death education and the management of fear of death via photo-voice: An experience among undergraduate students" was carried out with 6 authors; "Let's start with the end: Bibliodrama in an Italian death education course on managing fear of death, fantasy-proneness, and alexithymia with a mixed-method analysis" was carried out with 4 authors; "The effect of death education on fear of death amongst Italian adolescents: A nonrandomized controlled study" was carried out with 9 authors; "Beyond the wall: Death education at middle school as suicide prevention" was carried out with 5 authors; "Enhancing existential thinking through death education: A qualitative study among high school students" was carried out with 4 authors; "The hospice as a learning environment: A follow-up study with a palliative care team" was carried out with 5 authors; "A challenge for palliative psychology: Freedom of choice at the end of life among the attitudes of physicians and nurses" was carried out with 6 authors; "Imagine you have ALS": Death education to prepare for advance treatment directives" was carried out with 5 authors.

When the co-occurence of keywords network map was examined, it was found that the word co-worked with all words was "death education" (50 times). "Death" and "education" came after "death education" with 17 and 8 , respectively. The link of the word "death education" was 11 . Namely, "death education" had a link with 11 other keywords. These are; attitude to death, palliative care, bereavement, death and curriculum in the red set, death anxiety, children and grief in the green set and attitudes, online education and pedagogy of death in the blue set. The link of the second-placed word "death" was 8, while the link of the third-placed word "education" was 6. The keyword "death" had links with the keywords, attitude to death, education, bereavement, curriculum, death education, death anxiety, attitudes, nursing students. The keyword "education" had links with the keywords attitude to death, palliative care, bereavement, death, curriculum and attitudes. Keywords are important not only for determining the general trend of research topics, but also for determining the general usage of the terms or the concepts by nations. The keyword "pedagogy of education", for instance, was used by Spanish researchers. Unlike other scholars Spanish scholars often prefer using the term "pedagogy of death" or "death pedagogy" instead of "death education".

When the co- citation network map was examined, it is seen that clusters of four different colors were formed. When the blue cluster was examined, it was established that the works of the authors in this cluster (Kübler-Ross, Dadfar, Lester) was focused on the medical field and in the field of psychology (such as Templer). The authors in the green set in the center are not only highly cited writers but also the prominent names in the field of psychology. Kastenbaum, Neimeyer and Corr have numerous studies on death education. In brief, the cocitation network map included Wass and Testoni on an author-by-author basis, Death Studies and Omega Journal of Death and Dying on journal basis. In other words, the most cited authors were Wass and Testoni, while the most cited journals were Death Studies and Omega Journal of Death and Dying.

The first article on "Death Education" was written by an American researcher, J. A. Farmer. "Death Education - Adult Education in the Face of a Taboo" was published in an international journal Omega - Journal of 
Death and Dying in 1970. The first article on "Death Education" in Turkey was written in 2004 by Köylü, 34 years after Farmer's article. As of 2021 February the only bibliometric analysis on "Death Education" in the international literature was "Impacto de la producción científica acerca de la educación para muerte: Revisión bibliométrica en Scopus y Web of Science". It was conducted by Martinez-Heredia and Moreno in 2020, in Spanish.

While the studies on "Death Education" were rather rare, there was no bibliometric studies on "Death Education" in the national literature. In this regard, this research is expected to give perspective to those who will study not only on Death Education but also bibliometric analysis. On the other hand, since this is the first article written in English on "Death Education" by a Turkish researcher it is also expected to contribute to scholars in the international literature. Even though, significant results are obtained in the aforementioned sections, limitations exist in this present study. The main limitation of this research is the retrieval of data from only WoS, KCI and SciElo. Therefore, more useful results can be obtained expanding similar research through different databases (e.g. dissertation databases, book databases) are used.

The author carried out all parts of this research.

\section{Contributions of the Researchers}

\section{Financial Support and Acknowledgment}

The author declared that this research received no specific grant from any funding agency in the public, commercial, or not-for-profit sectors. The author would like to thank her mentor Assoc. Prof. Dr. Raşit Çelik who contributed the development of this article with his valuable comments.

\section{Conflict of Interest}

The author has disclosed no conflict of interest. 


\section{Kaynakça / References}

Aiken, R. L. (2001). Dying, Death, and Bereavement. Mahwah, NJ: Lawrence Erlbaum.

Bellibaş, M. Ş., \& Gümüş, S. (2018). Eğitim yönetiminde sistematik derleme çalışmaları. K. Beycioğlu, N. Özer, \& Y. Kondakçı (Ed.), Eğitim yönetiminde araştırma içinde (ss. 507- 575). Ankara: Pegem Akademi.

Bensley, Jr, L. B. (1975). Death education as a learning experience. SCIP No. 3, (ERIC Document Reproduction Service No. ED 115580). Access: https://eric.ed.gov/?q=death+education+as+a+learning\&id=ED115580

Bölükbaşı Macit, Z., \& Tümlü, C. (2019). Temel eğitim düzeyinde çalışan psikolojik danışmanlar için okullarda "Ölüm Eğitimi”. Eğitimde Nitel Araştırmalar Dergisi, 7(4), 1571-1589.

Brennan, M. (2014). ADEC. In M. Brennan (Ed.), The A-Z of death and dying: Social, medical, and cultural aspects (p. 6). Santa Barbara, CA: Greenwood.

Cobo, M. J., López-Herrera, A. G., Herrera-Viedma, E., \& Herrera, F. (2011). Science mapping software tools: Review, analysis, and cooperative study among tools. Journal of the American Society for Information Science and Technology, 62(7), 13821402 .

Çalık, M., \& Sözbilir, M. (2014). Parameters of content analysis. Education and Science, 39(174), 33-38.

Crase, D. R., \& Crase, D. (1985). Death education in the schools for older children. Issues in Comprehensive Pediatric Nursing, 8 , $345-363$.

Fonseca, L. M., \& Testoni, I. (2012). The emergence of thanatology and current practice in death education. OMEGA- Journal of Death and Dying, 64(2), 157-169.

Friesen, H., Harrison, J., Peters, M., Epp, D., \& McPherson, N. (2020). Death education for children and young people in public schools. International Journal of Palliative Nursing, 26(7), 332- 335.

İnci, F. (2008). Hemşirelere uygulanan ölüme ilişkin eğitimin hemşirelerin kaygl, depresyon ve tutumlarına etkisi (Yayınlanmamış doktora tezi). Hacettepe Üniversitesi, Ankara.

Köylü, M. (2004). Ölüm olayının çocuklar üzerine etkisi ve "Ölüm Eğitimi”. Ondokuz Mayls Üniversitesi Illahiyat Fakültesi Dergisi, 17(17), 95-120.

Martinez-Heredia, N., \& Moreno, M. B. (2020). Impacto de la producción científica acerca de la educación para muerte: Revisión bibliométrica en Scopus y Web of Science. Revista Iberoamericana de Educación, 82(2), 65-79.

Morgan, E. \& Morgan, J. (2001). Dealing creatively with death: a manual of death education and simple burial. Hinesburg, VT: Upper Access.

Silverman, A. (1987). Children and death education. In J. E. Schowalter, P. Buschman, P. R. Patterson, A. H. Kutscher, M. Tallmer, \& R. G. Stevenson (Eds.), Children and death: Perspectives from birth through adolescence (pp. 35- 40). New York, NY: Praeger.

Tanhan, F. (2007). Ölüm kaygıslyla baş etme eğitiminin ölüm kaygısı ve psikolojik iyi olma düzeyine etkisi (Yayınlanmamış doktora tezi). Ankara Üniversitesi, Ankara.

Özteke Kozan, H. İ. (2020). Okul psikolojik danışmanlığı ile ilgili yapılmış çalışmaların bibliyometrik analizi: 1980-2019. Okul Psikolojik Danışmanlı̆̆ Dergisi, 3(1), 1-28.

Van Eck, N. J., \& Waltman, L. (2010). Software survey: VOSviewer, a computer program for bibliometric mapping. Scientometrics, 84(2), 523-538.

Wass, H. (2003a). Death education. In R. Kastenbaum (Ed.), Macmillan encyclopedia of death and dying (pp. 211-219). New York, NY: Macmillan.

Wass, H. (2003b). Death education for children. In I. Corless, B. B. Germino, \& M. A. Pittman (Eds.), Dying, death, and bereavement: A challenge for living (pp. 25-41). New York, NY: Springer.

Zupic, I., \& Čater, T. (2015). Bibliometric methods in management and organization. Organizational Research Methods, 18(3), 429-472. 